\title{
Value Chain Analysis of Fish in Meghalaya: A Case Study in East Khasi Hills District
}

\author{
Sumithra, S., Ram Singh*, Anju Choudhury, L. Hemochandra, L. Geetarani Devi and \\ Richu Mathew Sunil
}

SSS, CPGS-AS, Central Agricultural University (Imphal), Umiam, Meghalaya, India

*Corresponding author: ramsingh.cau@gmail.com (ORCID ID: 0000-0002-3842-7777)

Received: $29-06-2021$

Revised: 24-08-2021

Accepted: 05-09-2021

\begin{abstract}
This study on 'Value Chain Analysis of Fish in Meghalaya: A case study in East Khasi Hills district' has been conducted in 2020-21 with specific objectives (1) To map the actors involved in the value chain of fish business. (2) To estimate the value addition in fish marketing by the value chain actors. The value chain actors were identified and the structure of the value chains was mapped. The study revealed that the most commonly followed method of value addition of fish in the study area are fermenting, drying and smoking. The cost incurred for making fermented fish was observed to be ₹ $21.50 / \mathrm{kg}$, ₹ $16.50 / \mathrm{kg}$ for dry fish and ₹ $37.50 / \mathrm{kg}$ for smoked fish. Additionally, net profit was found to be highest in value-added fish than compared to fresh ones. Therefore, value addition should be encouraged among fish farmers to increase net profit.

\section{Highlights}

(0 Actors observed in the value chain of fish were Fish seed vendors, Farmer, Wholesaler, Retailer, Fisheries department (retailer outlet), Local Trader cum Retailer, Farmer cum Processor and Consumers.

(0 Fermenting of fish is the most commonly used method of value addition in the study area followed by drying and smoking.

(- Value chain-5 was the most preferred channel for the disposal of value added products.
\end{abstract}

Keywords: Value Addition, Smoked Fish, Dry Fish, Fermented Fish

Fish is a cheap source of high-quality protein, and its consumption can help to prevent heart disease (Kareem, 2011). According to FAO, fish production at global level is estimated to about 179 million MT in 2018 of which 156 million MT were used for nonfood produce like fish meal and fish oil. China is a major fish producer in the world, 35 per cent of global fish production is from china.

India is now the second largest producer of fresh water fish in the world. In the fiscal year 2018-19, the fisheries sector contributed 1.24 percent to India's GDP. In 2018-19, the fisheries sector contributed 7.28 percent to India's agriculture sector (GoI, 2020). Fish and fish products remain one of the most traded food commodities in the world. Now fish and fish products have emerged as the biggest group in the exports of agricultural products from India, with 13.77 lakh MT in terms of quantity and $₹ 45,106.89$ crore in value. This accounts for around 10 per cent of the total exports and nearly 20 per cent of the agricultural export. Highest growth rate of fisheries sector contributing to the food basket, health, economic sector, employment and export of the country (NFDB, 2018).

How to cite this article: Sumithra, S., Singh, R., Choudhury, A., Hemochandra, L., Devi, L.G. and Sunil, R.M. (2021). Value Chain Analysis of Fish in Meghalaya: A Case Study in East Khasi Hills District. Economic Affairs, 66(3): 487-491.

Source of Support: None; Conflict of Interest: None 
The present study was conducted in the state of Meghalaya. Meghalaya is situated in the north eastern part of India. Fish is one of the most consumed foods in the North East region of India. Dry fish, as well as a variety of other traditional processed items such as shidal, smoked fish, and canned fish are popular among the people of this region. (Upadhyay, 2017)

\section{MATERIALS AND METHODS}

The present study was conducted in four village's viz., Madan bitaw, Pyndengkhah from Mawphlang block, Saikarap and Wahkaliar from Shella bholaganj of East Khasi Hills district of Meghalaya during 2020-21. Bara bazaar also called as kaiewduh in Shillong (distant market) and Sohra bazaar also called as lew sohra (local market) were selected as the major markets in which the fish is sold in the study area in East Khasi hills district of Meghalaya. Fish cultured for commercial purpose by the respondents of the study area were mainly sold to the agents/actors of these two markets.

A sample of 30 fish farmers from four villages were drawn for the study area and 33 numbers of market intermediaries such as wholesaler (11), retailer (19), local trader cum retailer (3) were taken as a respondents. Totally, the sample size was 63 which consist of both farmers and market intermediaries.

Both primary as well as secondary data were collected for the present study. First handed data were collected from the fish farmers and market intermediaries using pre-tested interview schedule. Secondary data regarding the highest production, maximum number of fish ponds and farmers among the blocks in the selected district etc., were collected from various published and unpublished sources viz., various research reports, Meghalaya State Aquaculture Mission and Directorate of Fisheries, Government of Meghalaya. The primary data collected on the current market price in the research area during calendar year of 2020-21 is used for analysis.

\section{Analytical tools}

\section{Mapping of Actors}

Different agencies or actors involved in fish business were identified and accordingly these were mapped by direct observation. Major markets selected purposively on the basis of product disposed off by the fish farmers of the study area were observed and based on the study, value chains were identified and actors were mapped. The data collected to map the fish (major species) value chains was based on the survey of fish farmers and market intermediaries at each node in the marketing of fish.

\section{Value addition}

The data on value addition by intermediaries including fish farmers were recorded by taking into consideration of various products prepared at each level of marketing. The formula to work out the value addition by each stakeholder,

Value addition $=$ Selling price of the product - Cost of the total inputs (kohls and Uhls, 1967)

\section{RESULTS AND DISCUSSION}

The present study is an attempt made to identify and map the actors involved in the value chain of fish in Meghalaya. Actors observed in the value chain of fish were Fish seed vendors, Farmer, Wholesaler, Retailer, Fisheries department (retailer outlet), Local Trader cum Retailer, Farmer cum Processor and Consumers.

Fish farmers from the study area purchasing fish seeds/fingerlings from private sector or from fishery department, they are usually called as fish seed vendors. The value chain starts from fish seed vendors and ends with ultimate consumer (Fig. 1). Table 1 represents the different fish species commonly cultured in the study area along with their local names, scientific names, common name and price in $₹ / \mathrm{kg}$. Value chain-5 was the most preferred channel for the disposal of value added products. Commonly cultured fish species in the study area includes Rohu (Labeo rohita), Copper mahseer (Neolissochilus hexagonolepis), Grass carp (Ctenopharyn godonidella), Catla (Catla catla), Common carp (Cyprinus carpio), Olive barb (Systomus sarana), Mrigal (Cirrhinus mrigala) and Kuria labeo (Labeo gonius) (Table 1).

\section{Value addition in fish}

Value addition is the process by which additional production operations whether in terms of labour, quality, utility, form, or other factors, raise the financial value of a product while also improving 
Table 1: Fish species commonly cultured in Meghalaya

\begin{tabular}{llll}
\hline Local name & Scientific name & Common name & Price (₹/kg) \\
\hline Kha ski & Labeo gonius & Kuria labeo & 200 \\
Kha saw & Neolissochilus hexagonolepis & Copper mahseer & 400 \\
Kha blang & Notopterus notopterus & Bronze featherback & 200 \\
Kha bah & Labeo rohita & Rohu & 280 \\
Kha dkhar & Cyprinus carpio & Common carp & 400 \\
Doh thli & Channa argus & Snake head & 250 \\
Doh sher & Canthophrys gongota & Gongota loach & 230 \\
Kha bamphlang & Ctenopharyn godonidella & Grass carp & 300 \\
Kha mirka & Cirrhinus mrigala & Mrigal & 200 \\
Kha baw & Catla catla & Catla & 250 \\
Kha putia & Systomus sarana & Olive barb & 220 \\
\hline
\end{tabular}

Fish value chain from fish seed vendors to consumers in Meghalaya

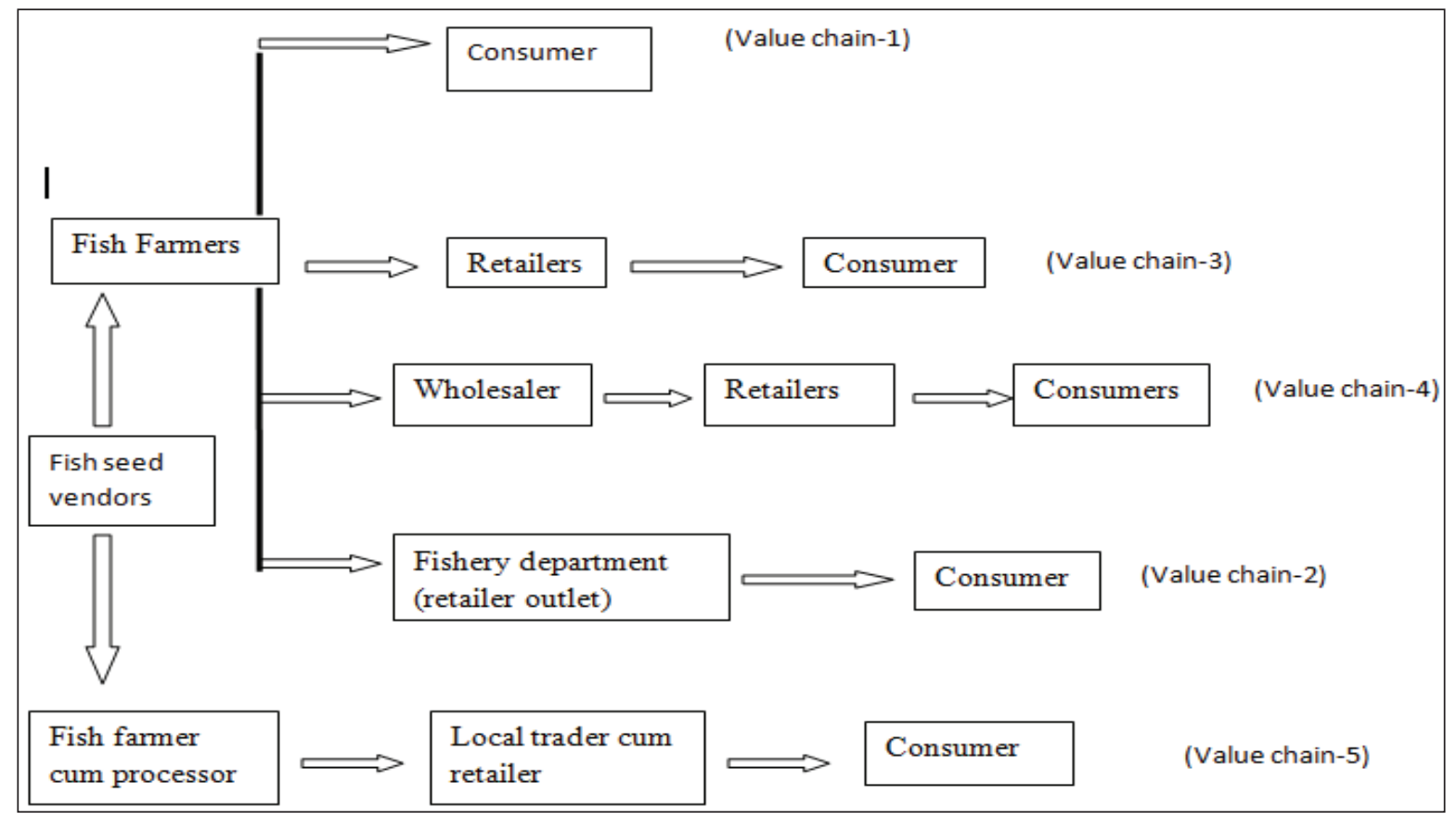

Fig. 1: mapping of actors in the value chain of fish

consumer preference. In case of fish value addition is mainly done to increase the shelf life. Value addition in fish is mainly done by fish farmer cum processors in the study area. Some of the fish farmers from the study area processed half of the quantity of fish that was harvested from their own ponds. The most common value addition done by the fish farmers from the study area are drying, smoking, fermenting. Tung tap is an ethnic fermented fish commonly prepared and consumed by tribes of the Khasi region of Meghalaya. Most important species used for fermenting was Danio $s p$. , species used for smoking was Labeo spp., species used for drying was Cirrhinus reba.

\section{Cost involved in value addition}

\section{Dry fish}

For the farmer cum processor maximum cost apart from price of the fresh fish were labour charges of ₹ 10.00 per $\mathrm{kg}$ followed by other costs such ₹ 3.00 per $\mathrm{kg}$ for salt $(0.83 \%)$, ₹ 2.00 per $\mathrm{kg}$ for the utensils and tools $(0.56 \%)$, ₹ 0.50 per $\mathrm{kg}$ for damage and spoilage $(0.14 \%)$ and $₹ 1.00$ per $\mathrm{kg}$ for other 
Table 2: Costs involved in value addition in fish (₹/kg)

\begin{tabular}{llll}
\hline Particulars & Dry fish & Fermented fish & Smoked fish \\
\hline (a) Price of fresh fish per kg & $230(63.89)$ & $240(63.16)$ & $250(62.50)$ \\
(b) Labour charge & $10.00(2.78)$ & $12.00(3.16)$ & $18.00(4.50)$ \\
(c) Fuel / wood & - & - & $6.30(1.58)$ \\
(d) Salt & $3.00(0.83)$ & $3.00(0.79)$ & $3.00(0.75)$ \\
(e) Turmeric powder & - & - & $4.50(1.13)$ \\
(f) Bamboo Tray, Airtight Bottle, Earthen Pots and & $2.00(0.56)$ & $4.00(1.05)$ & $5.20(1.30)$ \\
$\begin{array}{l}\text { Earthen Oven } \\
\text { (g) Damage/Spoilage }\end{array}$ & $0.50(0.14)$ & $2.50(0.66)$ & $0.50(0.13)$ \\
(h) Others & $1.00(0.28)$ & - & - \\
\hline Total cost involved in value addition (b to h) & $16.50(4.58)$ & $21.50(5.66)$ & $37.50(9.38)$ \\
\hline Net profit after value addition & $113.50(31.53)$ & $118.50(31.18)$ & $112.50(28.13)$ \\
\hline Farmer cum processor sales price & $360(100)$ & $380(100)$ & $400(100)$ \\
\hline
\end{tabular}

Note: Figures given in parentheses shows percentages to total.

Table 3: Net profit after value addition $(₹ / \mathrm{kg})$

\begin{tabular}{llllll}
\hline S1. No. & Fresh fish price $(₹ / \mathbf{k g})$ & Particulars & Cost incurred $(₹ / \mathbf{k g})$ & Selling price $(₹ / \mathbf{k g})$ & Net profit $(₹ / \mathbf{k g})$ \\
\hline 1 & 230 & Dry fish & 16.50 & 360 & 113.50 \\
2 & 240 & Fermented fish & 21.50 & 380 & 118.50 \\
3 & 250 & Smoked fish & 37.50 & 400 & 112.50 \\
\hline
\end{tabular}

miscellaneous purposes. The total cost incurred was ₹ 246.50 per $\mathrm{kg}$. The selling price of dry fish was identified to be of ₹ 360 per $\mathrm{kg}$. The net profit received by the processor after value addition has been worked out to be of ₹ 113.50 per $\mathrm{kg}$.

\section{Fermented fish}

For the farmer cum processor maximum cost apart from price of the fresh fish were labour charges of ₹ 12.00 per $\mathrm{kg}$ followed by other costs of ₹ 3.00 per $\mathrm{kg}$ such as for salt $(0.79 \%)$, ₹ 4 per $\mathrm{kg}$ for the utensils and tools $(0.63 \%)$, ₹ 2.50 per $\mathrm{kg}$ for damage and spoilage $(0.66 \%)$. The total cost incurred was ₹ 261.50 per $\mathrm{kg}$. The selling price of fermented fish was identified to be ₹ 380 per $\mathrm{kg}$. The net profit received by the processor after selling the fermented fish was ₹ 118.50 per $\mathrm{kg}$.

\section{Smoked fish}

The different costs required for the preparation of smoked fish apart from the price of fresh fish were labour charges of ₹ 18 per $\mathrm{kg}$ followed by other costs such ₹ 6.30 per $\mathrm{kg}$ for fuel (1.58\%), ₹ 5.20 per $\mathrm{kg}$ for the earthen oven and other tools $(1.30 \%)$,
₹ 4.50 per $\mathrm{kg}$ for turmeric powder $(1.13 \%)$, ₹ 0.50 per $\mathrm{kg}$ for damage and spoilage $(0.13 \%)$. The total cost incurred was ₹ 287.50 per $\mathrm{kg}$. The selling price of smoked fish was identified to be ₹ 400 per $\mathrm{kg}$. The net profit received by the processor after value addition was ₹ 112.50 per $\mathrm{kg}$.

Fermented fish was observed to have a higher net profit ( $₹ 118.50 / \mathrm{kg}$ ) than other two value- added products (Table 3 ). It can be concluded that value added products have relatively higher price than fresh ones in the market. Similar results were observed by Meitei et al. (2017) and Kotni, (2016).

\section{CONCLUSION}

Value chain-5 was the most preferred channel for the disposal of value added products in the study area. Fermenting of fish is the most commonly used method of value addition in the study area followed by drying and smoking. Value added products have relatively higher price than fresh one in the market. Value addition should be encouraged among fish farmers in the state through some training programmes. A traditional value addition method is not hygiene and it's of less quantity. Fisheries 
department of the state should take steps to increase value addition centres.

\section{ACKNOWLEDGEMENTS}

The authors of the study are grateful to the Central Agricultural University, Imphal for providing the resources necessary to perform this master's research in the field of agricultural economics, from which this manuscript was derived.

\section{REFERENCES}

FAO. The State of World: Fisheries and Aquaculture. Fisheries Department. Rome. 2020. (Available from http://www. fao.org > state-of-fisheries-aquaculture. Assessed on 6 March 2021).

Handbook on Fisheries Statistics. 2020. Department of Fisheries, Ministry of Fisheries, Animal Husbandry and Dairying, Govt. of India, New Delhi. (available from http://dof.gov.in/sites/default/filess/Handbook on FS 2020. pdf Assessed on 8 January 2021).
Kareem, R.O. 2011. Analysis of economic efficiency of artisanal fisheries in Osun State, Nigeria. Ph.D. Thesis, submitted to Obafemi Awolowo University, Ile-Ife, Osun State, Nigeria.

Kohls, R.L. and Uhls, J.N. Marketing of Agricultural Products. Macmillan Publishing Company. New York. USA. 1967.

Kotni, V.V. 2016. Value chain management practices in marine fisheries: A case study of Andhra Pradesh. Int. J. Managing Value and Supply Chains, 7(2): 9-19.

Meitei, N., Singh, R. and Feroze, S.M. 2019. Economics of value addition in fish in Manipur state of India: Empirical analysis. J. Fish. Res., 3(1): 18-25.

The National Fisheries Development Board (NFDB, 2018). Annual report. Department of Animal Husbandry, Dairying and Fisheries, Ministry of Agriculture and Farmers Welfare, Government of India. (available from http://nfdb.gov.in/annual-report. Assessed on 10 December 2020).

Upadhyay, A.D., Pandey, D.K. and Dhar, B. 2017. Value chain analysis of dry fish in north-east region of India. In Financing Agriculture Value Chains in India (pp. 143-162). Springer, Singapore. 
